\title{
Pelatihan Keterampilan Berbicara Menggunakan Media Gambar Berseri Pada Anak-Anak di RT 9 Kelurahan Benpasi
}

\author{
Rince Jalla Wabang ${ }^{1)}$, Maria Rosalinda Talan ${ }^{2)}$ \\ Program Studi Pendidikan Bahasa dan Sastra Indonesia, Fakultas Ilmu Pendidikan \\ Unversitas Timor, Indonesia ${ }^{1), 2)}$ \\ Pos-el: rincejalla@unimor.ac.id,maria_rosalindatalan@yahoo.co.id
}

\author{
\begin{tabular}{l|l|l} 
Dikirim: 15, 06, 2020 & Direvisi: 09, 07, 2020 & Diterbitkan: 31, 08,2020
\end{tabular}
}

\begin{abstract}
Abstrak
Media gambar berseri merupakan salah satu media yang sangat efektif dalam pembelajaran keterampilan berbahasa di sekolah dasar dengan fokus berbicara. Media ini menyajikan gambar yang berurutan sehingga dapat menyajikan informasi yang nyata dan lengkap. Tujuan pengabdian ini adalah untuk meningkatan keterampilan berbicara menggunakan media gambar berseri pada anak-anak yang merupakan peserta didik kelas IV dan V SD yang tersebar di RT 9 Kelurahan Benpasi. Metode yang digunakan adalah metode ceramah, tanya jawab, dan praktik. Prosedur pelatihan keterampilan berbicara dilakukan dengan tahap 1) menjelaskan pentingnya berbicara yang baik dan benar, 2) melakukan tanya jawab, 3) memberikan waktu kepada anak-anak untuk berbicara mengenai pandemik virus corona tanpa adanya rangsangan gambar berseri, 4) menampilkan beberapa gambar berseri, 5) memberikan contoh berbicara menggunakan rangsangan gambar berseri, 6) memberikan kesempatan kepada anak-anak untuk berbicara menggunakan rangsangan gambar berseri; dan 7) melakukan evaluasi. Hasil dari pengabdian ini menunjukkan bahwa media gambar dapat meningkatkan motivasi dan keterampilan berbicara anak. Anakanak lebih antusias atau semangat dalam berlatih berbicara jika diberikan media gambar berseri dibandingkan dengan tanpa menggunakan media. Keterampilan berbicara anak juga meningkat dengan adanya penggunaan media gambar berseri. Dengan demikian, media gambar berseri sangat direkomendasikan kepada guru di sekolah dasar agar digunakan dalam proses pembelajaran di kelas.
\end{abstract}

\section{Kata Kunci: media, gambar berseri, berbicara}

\section{Abstract}

Serial picture media is one of the most effective media in learning languange skills in Primary schools with focus on speaking skills. This media presents sequential pictures so it can present real and complete information. The purpose of this reserach is to improve speaking skills using Media of Sereal Pictures in children of Elementary School grade IV and V which spread in RT 09 of Kelurahan Banpasi. The method used in this research are the method of lecture, question and answer and also prcatice. The procedure of speaking skills training is done in stages 1) explain the importance of speaking good and right, 2) do question and answer, 3) give a time for the students to speak about Pandemic Corona Virus without serial picture media stimulation, 4) show some serial picture media, 5) give example use sereal picture media in speaking, 6) give chance for students to speak using serial picture media stimulation, 7) do an evaluation. The result of this research shows that serial picture media improve children's motivation and speaking skills. The students are more enthusiastic in practicing speaking if given a serial picture media, when compared without using serial picture media. Thus the serial picture media is highly recomended for teachers in elementary schools to be used in learning process in the classroom.

Keywords: media, serial picture, speaking 


\section{LATAR BELAKANG}

Bahasa memegang peran sentral dalam kehidupan sosial manusia. Tanpa bahasa, manusia tidak bisa menyampaikan pikiran, gagasan, pendapat, maupun perasaannya kepada orang lain. Selain berfungsi sebagai alat ekspresi diri, alat integrasi dan adaptasi, dan alat kontrol sosial, bahasa juga memiliki fungsi yang sangat penting yaitu sebagai alat komunikasi (Kurniawan, 2015:5). Dalam menjalankan fungsi komikasi ini, penutur/penulis dituntut agar menggunakan bahasa yang komunikatif. Artinya, pembicara/penulis hendaknya mengggunakan bahasa yang dapat dipahami oleh penyimak/pembaca. Oleh karena itu, dibutuhkan keterampilan dalam berkomunikasi.

Keterampilan yang harus dimiliki dalam kaitannya dengan bahasa adalah keterampilan menyimak, keterampilan berbicara, keterampilan membaca, dan keterampilan menulis. Keterampilan menyimak dan keterampilan membaca merupakan kegiatan reseptif, sedangkan keterampilan berbicara dan keterampilan menulis termasuk kegiatan produktif. Oleh karena sifatnya yang produktif, seseorang dituntut untuk terampil dalam berbicara maupun menulis agar kegiatan komunikasi dapat berjalan dengan baik dan sesuai dengan apa yang diharapkan.

Salah satu keterampilan yang penting adalah keterampilan berbicara. Berbicara adalah salah satu alat komunikasi penting untuk dapat menyatakan diri sebagai anggota masyarakat. Dengan kata lain, untuk menghubungkan sesama anggota masyarakat diperlukan aktivitas berbicara. Dalam pemakaiannya, seseorang dituntut untuk terampil berbicara agar meningkatkan kualitas hubungan sosialnya dan untuk kepentingan dirinya sendiri seperti pengembangan karier. Secara singkat Tarigan (1990:149) menyatakan bahwa keterampilan berbicara adalah keterampilan menyampaikan pesan melalui bahasa lisan. Mulyati dan Isah Cahyani (2015:1.12), menguraikan indikator keterampilan berbicara adalah 1) mengucapkan bunyi bahasa secara jelas; 2) menggunakan tekanan, nada, dan intonasi dengan tepat; 3) menggunakan bentuk kata, urutan kata, dan pilihan kata dengan tepat; 4) menggunakan ragam bahasa secara tepat; 5) menyampaikan kalimat utama dengan jelas; 5) menyampaikan kalimat penjelas untuk mendukung kalimat utama; 6) mengusahakan wacana berkesinambungan secara serasi.

Pada kenyataannya masih banyak masalah yang ditemukan dalam aktivitas berbicara seperti kesulitan menyampaikan ide/gagasan/perasaan serta terjadinya kesalahpahaman di antara pembicara dan penyimak. Dengan demikian, seorang pembicara dituntut untuk terampil berbicara dalam menuangkan ide/gagasan atau dalam menyampaikan informasi kepada orang lain dengan baik sehingga penyimak dapat memahaminya sesuai maksud pembicara dan proses komunikasi dapat berjalan dengan lancar.

Dalam konteks pembelajaran peserta didik mengakui mengalami kesulitan dalam berbicara. Kegiatan ini dianggap sebagai aktivitas yang berat bagi peserta didik. Peserta didik biasanya susah menyampaikan ide-idenya dan ada juga yang tidak mampu bercerita di depan kelas. Singkatnya, peserta didik enggan berbicara sehingga mempengaruhi keterampilan berbicaranya dan keaktifan belajarnya di kelas. Faktor-faktor yang mempengaruhi peserta didik tidak terampil dalam berbicara adalah karena penggunaan pendekatan, model, metode, atau media yang kurang tepat, kurang adanya motivasi baik motivasi internal dan eksternal, sikap 
mental, dan faktor latihan. Untuk mengatasi kesulitan ini, diperlukan berbagai aspek yang menunjang dalam keterampilan berbicara peserta didik salah satunya adalah penggunaan media pembelajaran yang efektif.

Menurut Rathwell dan Kazanas (1992: 224) media pembelajaran berkisar dari media yang kompleks sampai media yang sederhana. Media yang kompleks memerlukan banyak persiapan terlebih dahulu, sedangkan media sederhana tidak memerlukan banyak persiapan, misalnya pengalaman langsung (seperti menggunakan alam sebagai media pembelajaran). Berdasarkan kerucut pengalaman Edgar Dale, semakin langsung suatu objek yang dipelajari maka semakin konkret pengetahuan siswa, sedangkan semakin tidak langsung suatu ojek maka semakin abstrak pengetahuan siswa (Sanjaya 2008:202). Pengalaman belajar dengan media gambar termasuk pengalaman belajar yang lebih konkret jika dibandingkan dengan pengalaman belajar yang hanya menggunakan bahasa verbal. Jika diklasifikasikan menurut pendapat Rathwell dan Kazanas, media gambar termasuk media yang sederhana karena tidak banyak memerlukan persiapan. Di era digital saat ini, gambar bisa didapatkan dengan mudah dari alam (otentik) maupun dari internet. Oleh karena itu, media dapat dimanfaatkan dalam pembelajaran sehingga dapat menciptakan pembelajaran yang bermakna bagi peserta didik.

Berdasarkan berbagai hasil penelitian, media gambar berseri merupakan salah satu media yang sangat efektif dalam pembelajaran keterampilan berbahasa dengan fokus berbicara. Mediaini menyajikangambaryang berurutan sehinggadapat menyajikan informasi yang nyatadanlengkap. Selain itu, penggunaanmedia gambar berseri dapatmembantu dan memotivasi pesertadidik untuk memusatkan perhatianterhadapmateriyangdisampaikan. Dalam kegiatan latihan berbicara peserta didik akan memiliki konsep dalam menyajikan informasi karena didukung dengan media gambar berseri tersebut. Dengan demikian, informasi yang disajikan peserta didik dipastikan runtun dan tidak mengulang-ulang kalimat.

Media gambar berseri sangat cocok digunakan untuk melatih keterampilan berbicara pada anak-anak sekolah dasar sebagai rangsangan. Hal ini dimaksudkan agar anak-anak memiliki konsep yang sistematis dalam menyampaikan ide/gagasan/perasaan kepada orang lain. Seorang guru, orang tua, atau masyarakat perlu mengakomodasi anak-anak dalam melatih keterampilan berbicara mereka. Menurut Saddhono dan Slamet Y. (2014:57) bila lingkungan sering mengajak dan mengakomodasi anak untuk belajar dan berlatih berbicara, maka anak tersebut akan terampil berbicara. Sebaliknya jika lingkungan tidak mengajak dan mengakomodasi anak untuk belajar dan berlatih berbicara, maka anak akan kesulitan memperoleh keterampilan berbicara.

Masalah yang terjadi seperti yang diuraikan di atas menjadi latar belakang pelaksanaan pengabdian ini. Pengabdian ini difokuskan pada upaya meningkatan keterampilan berbicara menggunakan media gambar berseri pada anak-anak yang merupakan peserta didik kelas IV dan V SD yang tersebar di RT 9 Kelurahan Benpasi.

\section{METODE}

Kegiatan pengabdian pada mayarakat ini dilaksanakan di RT 9 Kelurahan Benpasi. Sasaran dalam pengabdian ini adalah anak-anak yang merupakan peserta didik kelas IV dan V SD. 
Pemilihan lokasi ini dikarenakan para peserta didik saat ini sedang menjalankan program belajar dari rumah yang diakibatkan oleh pandemik virus corona. Kelas IV dan V termasuk kelas pada level kelas tinggi sehingga cocok menjadi sasaran pelatihan berbicara karena konten berbicara berhubungan dengan pandemik virus corona. Anak-anak pada tingkatan ini sudah tidak asing dengan konten ini sehingga dapat dengan mudah menyesuaikan diri. Kegiatan pengabdian ini dilaksanakan selama dua hari.

Pelaksanaan kegiatan pengabdian pada masyarakat ini mengunakan metode ceramah, tanya jawab, dan praktik. Prosedur pelatihan keterampilan berbicara dilakukan dengan tahap 1) menjelaskan pentingnya berbicara yang baik dan benar, 2) melakukan tanya jawab, 3) memberikan waktu kepada anak-anak untuk berbicara mengenai pandemik virus corona tanpa adanya rangsangan gambar berseri, 4) menampilkan beberapa gambar berseri, 5) memberikan contoh berbicara menggunakan rangsangan gambar berseri, 6) memberikan kesempatan kepada anak-anak untuk berbicara menggunakan rangsangan gambar berseri; dan 7) melakukan evaluasi.

\section{HASIL DAN PEMBAHASAN}

Kegiatan pengabdian ini dilaksanakan selama dua hari. Pada hari pertama yakni tahap pengenalan, tim pengabdi datang ke ketua RT 9 Kelurahan Benpasi untuk berkoordinasi dan menyiapkan anak-anak yang akan mengikuti pelatihan. Saat berkoordinasi, ketua RT dan tim pengabdi bersepakat bahwa peserta pelatihan tidak boleh lebih dari delapan orang mengingat saat ini sedang terjadi wabah virus corona. Tim pengabdi diberikan satu rumah warga sebagai tempat pelatihan. Selanjutnya tim pengabdi melakukan setingan tempat dengan memperhatikan jarak dan protokol kesehatan lainnya. Selanjutnya anak-anak dihadirkan untuk mengikuti pelatihan ini. Setelah itu, tim langsung memulai kegiatan pelatihan dengan tahapan ssebagai berikut. 1) Tim pengabdi memperkenalkan diri dan dilanjutkan dengan perkenalan anak-anak agar terjalin keakraban di antara tim pengabdi dan peserta pelatihan. 2) Tim pengabdi menjelaskan tujuan pengadaan pelatihan kepada anak-anak. 3) Tim pengabdi menjelaskan pentingnya keterampilan berbicara. 4) Tim pengabdi melakukan tanya jawab seputar pengalaman anak-anak dalam berbicara dalam konteks berbicara di kelas maupun berbicara di muka umum seperti dalam perlombaan-perlombaan. Dalam kesempatan ini, anak-anak menyampaikan bahwa mereka pernah berbicara di kelas pada saat guru bertanya dan pernah mengikuti lomba bercerita antar kelas di lingkungan sekolah. Tim pengabdi memberi apresiasi kepada anak-anak agar memotivasi mereka untuk tetap berlatih berbicara karena pada dasarnya suatu keterampilan harus diperoleh melalui latihan secara berkesinambungan. 5) Tim pengabdi memberi kesempatan kepada anak-anak untuk menyampaikan himbauan dalam menghadapi virus corona. Pada kesempatan ini, anak-anak dengan antusias menyampaikan himbauan-himbauan namun tidak teratur dan selalu mengulang-ulang kalimat yang sudah disampaikan. Hasil rata-rata keterampilan yang diperoleh anak-anak adalah 58 yang dikonversikan dengan Permendikbud Nomor 23 Tahun 2016 masuk kategori kurang terampil berbicara.

Hari yang kedua yakni tahap aksi, mengikuti tahapan berikut. 1) Tim pengabdi memasuki ruang pengabdian dan membuka kegiatan pengabdian. 2) Tim pengabdi menampilkan beberapa 
gambar berseri dan menjelaskan tujuan penggunaan media gambar itu dalam berbicara. 3) Tim pengabdi memberi contoh berbicara berdasarkan gambar berseri yang disiapkan. Tim pengabdi memberi contoh dengan memperhatikan indikator keterampilan berbahasa yakni a) mengucapkan bunyi bahasa secara jelas; b) menggunakan tekanan, nada, dan intonasi dengan tepat; c) menggunakan bentuk kata, urutan kata, dan pilihan kata dengan tepat; d) menggunakan ragam bahasa secara tepat; e) menyampaikan kalimat utama dengan jelas; f) menyampaikan kalimat penjelas untuk mendukung kalimat utama; dan g) mengusahakan wacana berkesinambungan secara serasi. 4) Tim pengabdi memberikan kesempatan kepada anak-anak untuk berlatih berbicara menggunakan gambar berseri. Pada kesempatan ini, anak-anak sudah bisa menyampaikan informasi dari gambar tersebut secara teratur dan tidak mengulang-ulang kalimat. Selain itu, tim pengabdi langsung memberikan komentar terkait kekurangan-kekurangan yang masih tampak pada latihan itu, memberikan solusi untuk memperbaiki, dan langsung memberi kesempatan untuk melakukan perbaikan. Kegiatan ini dilakukan secara terus menerus hingga menghasilkan kualitas berbicara yang lebih baik daripada sebelumnya. 5) Tim pengabdi melakukan evaluasi dengan cara menampilkan gambar berseri lainnya lalu meminta anak-anak untuk berbicara berdasarkan gambar yang diberikan. Tujuan kegiatan evaluasi adalah untuk mengetahui sejauh mana keterampilan berbicara anak-anak setelah diberikan perlakuan atau pelatihan. Hasil rata-rata keterampilan yang diperoleh anak-anak adalah 76 yang dikonversikan dengan Permendikbud Nomor 23 Tahun 2016 masuk kategori cukup terampil berbicara.

Berdasarkan observasi, ditemui kenyataan bahawa anak-anak sangat termotivasi dalam mengikuti kegiatan pelatihan. Hal ini disebabkan karena tim pengabdi menggunakan media yakni berbagai gambar yang menarik yang merangsang produktifitas berbicara anak-anak sehingga berujung pada efektifitas pelatihan. Hal ini sejalan dengan pendapat Sudrajat (2008:1) bahwa media pembelajaran digunakan dalam pembelajaran dapat mempengaruhi efektivitas pembelajaran. Menurutnya media memiliki beberapa fungsi, yakni 1) dapat mengatasi keterbatasan pengalaman yang dimiliki oleh para peserta didik; 2) dapat melampaui batasan ruang kelas; 3) memungkinkan adanya interaksi langsung antara peserta didik dan lingkungannya; 4) menghasilkan keseragaman pengamatan; 5) menanamkan konsep dasar yang benar, konkrit, dan realistis; 6) membangkitkan keinginan dan minat baru; 7) membangkitkan motivasi dan merangsang anak untuk belajar; dan 8) memberikan pengalaman yang integral/menyelutuh dari yang konkrit sampai dengan abstrak. Dengan demikian dapat dikatakan bahwa kehadiran media gambar berseri turut mendongkrak motivasi anak-anak dalam melatih keterampilan berbicaranya.

Selain memberikan motivasi, anak-anak juga menjadi terampil berbicara setelah menggunakan media gambar berseri. Hal ini berbeda dari keadaan sebelumnya yang menunjukkan anak-anak belum begitu terampil berbicara karena tidak diberikan rangsangan media. Anak-anak kesulitan menuangkan ide-idenya berdasarkan topik yang diberikan tim pengabdi. Namun, setelah menggunakan media gambar berseri, anak-anak mampu menginterprestasikan isi cerita sesuai dengan imajinasinya dan dapat mengungkapkan hasil pengamatan pada media gambar berseri dengan bahasa yang runtut/sistematis dan bermakna. 
Kenyataan ini sejalan dengan berbagai penelitian, salah satunya penelitian Estika, dkk (2018) yang mengungkapkan bahwa penggunaan media gambar berseri dapat meningkatkan keterampilan berbicara anak. Oleh karena itu, pengabdian ini turut membuktikan kebenaran berbagai penelitian yang mengungkapkan bahwa media gambar berseri dapat meningkatkan keterampilan berbicara anak.

\section{KESIMPULAN}

Berdasarkan hasil pengabdian menunjukkan bahwa media gambar dapat meningkatkan motivasi dan keterampilan berbicara anak. Anak-anak lebih antusias atau semangat dalam berlatih berbicara jika diberikan media gambar berseri dibandingkan dengan tanpa menggunakan media. Keterampilan berbicara anak juga meningkat dengan adanya penggunaan media gambar berseri. Dengan demikian, media gambar berseri sangat direkomendasikan kepada guru agar digunakan dapat dalam proses pembelajaran di kelas. Selain itu, orang tua juga dapat menggunakan media gambar berseri untuk membantu peningkatan keterampilan berbicara di rumah.

\section{DAFTAR PUSTAKA}

Kurniawan, Khaerudin, 2015. Bahasa Indonesia Keilmuan untuk Perguruan Tinggi. Bandung: Refika Aditama.

Mulyati, Yeni dan Isah Cahyani. 2015. Keterampilan Berbahasa Indonesia SD. Tangerang Selatan: Universitas Terbuka.

Rothwell, William J. dan Kazanas H. C. 1992. Mastering the Instructional Design Process: A Systematic Approach. San Fransisco: Jossey-Bass.

Saddhono K dan Slamet Y. 2014. Pembelajaran Keterampilan Berbahasa Indonesia: Teori dan Aplikasi. Yogyakarta: Graha Ilmu.

Sanjaya, Wina. 2008. Strategi Pembelajaran Berorientasi Standar Proses Pendidikan. Jakarta: Kencana.

Tarigan, Djago. 1990. Materi Pokok Pendidikan Bahasa Indonesia 1. Buku 1: Modul 1-6. Jakarta: Depdikbud.

Sudrajat, Ahmad. 2008. Pengertian Pendekatan, Strategi, Metode, Teknik dan Model Pembelajaran. Bandung: Sinar Baru Algensindo.

Estika, Vera., S. Halidjah dan Sugiyono. 2018. Peningkatan Keterampilan Berbicara Menggunakan Media Gambar Berseri di Kelas III Sekolah Dasar. Jurnal Pendidikan dan Pengajaran Khatulistiwa, 7 (3) : 1-9. 